\title{
Comparative study of the proliferative ability of skeletal muscle satellite cells under microwave irradiation in fractures with titanium alloy internal fixation in rabbits
}

\author{
YUZHEN ZOU, GANG WANG, YIMING XU and YUEHONG BAI \\ Department of Rehabilitation, Shanghai Jiao Tong University Affiliated Sixth People's Hospital, Shanghai 200233, P.R. China
}

Received August 16, 2016; Accepted May 11, 2017

DOI: $10.3892 / \mathrm{etm} .2018 .6812$

\begin{abstract}
The aim of the present study was to investigate the proliferation of skeletal muscle satellite cells (MSCs) under different amounts of microwave irradiation in fractures with titanium alloy internal fixation. A total of 45 male New Zealand adult white rabbits were used to establish a femoral shaft fracture and titanium alloy internal fixation model. The rabbits were randomly divided into the control group (group A) and the experimental groups (groups B and C). For 15 days, groups $\mathrm{B}$ and $\mathrm{C}$ were exposed to microwave treatment ( 25 or $50 \mathrm{~W}$, respectively) for $10 \mathrm{~min}$ per day. The quadriceps femoris muscle was used for the isolation and culture of MSCs in vitro. The cultured cells were identified using cellular immunohistochemical staining. Transmission electron microscopy was used to observe mitochondrial ultrastructure damage, MTT assays were used to detect cell viability and cell cycle phases were analyzed by flow cytometry. The results revealed that, following 48 or $72 \mathrm{~h}$ of culture, cell viability was significantly greater in group B compared with group A, and was significantly lower in group $\mathrm{C}$ compared with group $\mathrm{A}(\mathrm{P}<0.05)$. Compared with group $\mathrm{A}$, the percentage of the cell population in the $\mathrm{G} 0 / \mathrm{G} 1$ phase in group B was significantly decreased $(\mathrm{P}<0.05)$ and the proportion in the $\mathrm{S}$ and $\mathrm{G} 2 / \mathrm{M}$ phases was increased $(\mathrm{P}<0.05)$. These results were reversed in group $\mathrm{C}$; the percentage of cells in the $\mathrm{S}$ and $\mathrm{G} 2 / \mathrm{M}$ phases was significantly lower $(\mathrm{P}<0.05)$ and in the G0/G1 phase was significantly higher $(\mathrm{P}<0.05)$ than in group A. These results suggested that in the healing of fractures with titanium, the proliferation of MSCs is significantly affected by microwave radiation in a dose-dependent manner.
\end{abstract}

Correspondence to: Professor Yuehong Bai, Department of Rehabilitation, Shanghai Jiao Tong University Affiliated Sixth People's Hospital, 600 Yishan Road, Shanghai 200233, P.R. China E-mail: aibyhw@126.com

Key words: microwaves, fracture fixation, internal, satellite cells, skeletal muscle, cell proliferation

\section{Introduction}

Due to an aging population and an increasing number of traffic accidents, the incidence of bone fractures continues to rise, which was reported as being $6.42 \%$ in people aged over 50 (1). Open reduction and internal fixation has become a common surgical treatment for fractures (2). Internal fixation has substantial healing advantages as it fixes the fracture and maintains the morphological structure and biomechanics of the broken bones, allows for improved pain control, and prevents pain and joint stiffness by facilitating motion in the postoperative phase (3). Although the vast majority of fractures treated with modern internal fixation techniques will heal, complications do occasionally occur (4). To easily mount the implant, the soft tissue and periosteum are extensively dissected, which increases the likelihood of infection, neurovascular injury and skin flap necrosis $(5,6)$. All of the aforementioned complications may cause visible and serious consequences, including delayed union and nonunion (7). Such complications may be life-altering due to the symptoms and also the economic burden they place on the patient (8). Furthermore, they may cause a significant financial impact on health care systems $(9,10)$. Therefore, accelerating early fracture healing is necessary and important to prevent short- and long-term complications and to minimize the occurrence of delayed union and nonunion.

Bone is much denser than muscle, fat or hematoma, and so most forms of therapeutic heating are unable to penetrate it; however, microwaves are able to penetrate bone to reach therapeutic values (11). High-frequency microwaves are used as a clinical hyperthermia method to heat deep tissues (12). Microwave energy may be directly focused on localized areas without affecting the temperature in adjacent tissues (13). Hyperthermia induced by microwaves increases local blood perfusion and consequently nutrient and oxygen supply to the heated region. It also alleviates pain, speeds up metabolism, enhances apoptosis and stimulates new bone formation following injury (14-16).

The use of microwave diathermy in fracture healing is not a novel concept. There has been an abundance of relevant reports and research since 1993, when Leon et al $(17,18)$ and Chang et al (19) systematically demonstrated that microwave diathermy promoted bone deposition in fracture healing both in vitro and in vivo. As a considerable amount of microwave 
energy may be reflected or refracted at the interfaces between tissue and the metal implant used in orthopedic surgery (20), there is controversy regarding whether microwaves should be applied to fractures with metal-implanted internal fixation. Historically, it was considered an absolute contraindication $(21,22)$, but in recent years opinions have changed and reports have increasingly questioned whether the contraindication is based on consensus or scientific evidence.

Internal fixation of fractures using titanium alloys has gained popularity $(23,24)$. Given that the magnetic permeability and electric conductivity of titanium alloy is lower than conventional biomedical metal implants $(25,26)$. Ye et al (27) performed two randomized controlled studies and demonstrated that $25 \mathrm{~W}$ microwave $(2,450 \mathrm{MHz})$ improved the healing of fractures with titanium alloy internal fixation without irreversible heat damage $\left(<41^{\circ} \mathrm{C}\right)$ in a rabbit model. Ye et al (28) also reported that the temperature of muscle tissue adjacent to titanium alloy implants is beyond the scope of security $\left(>41^{\circ} \mathrm{C}\right)$ when the power of microwave irradiation is tuned to $50 \mathrm{~W}$. This report alone is insufficient and further research is required to reach a new consensus. The aim of the present study was to further verify the security and feasibility of microwave therapy from another aspect by comparing the proliferative ability of skeletal muscle satellite cells (MSCs) under 0,25 and $50 \mathrm{~W}$ of microwave irradiation.

\section{Materials and methods}

Ethics statement. All animal welfare and experimental procedures involving animals were conducted in strict conformity with the recommendations in the Guide for the Care and Use of Laboratory Animals of National Laboratory Animals and protocols were specifically approved by the Animal Welfare and Ethics Committee of Shanghai Sixth People's Hospital [Permit no. SYXK (HU) 2011-0128; Shanghai, China].

Animals and grouping. A total of 45 healthy adult white New Zealand male rabbits (Shanghai Biomodel Organism, Shanghai, China) aged 16-18 weeks and weighing 2.2-3.0 kg (mean, $2.5 \mathrm{~kg}$ ) were supplied by the Animal Laboratory Center of Shanghai Jiao Tong University Affiliated Sixth People's Hospital. The rabbits were fed with a standard diet and were allowed access to forage and drinking water. Rabbits were housed at a constant temperature $\left(25^{\circ} \mathrm{C}\right)$ and relative humidity (45-60\%) with a $12 \mathrm{~h}$ light/dark cycle.

The rabbits were randomly and evenly assigned into i) the control group (group A), ii) the $25 \mathrm{~W}$ microwave treatment group (group B) or iii) the $50 \mathrm{~W}$ microwave treatment group (group C) after a week of adjustable feeding. No significant differences were observed in age or weight between groups following randomization. All rabbits underwent orthopedic surgery to create a femoral shaft fracture and titanium alloy internal fixation model. Following surgery, group A was left untreated and served as the control. Group B were treated with $25 \mathrm{~W}$ microwaves and group $\mathrm{C}$ with $50 \mathrm{~W}$ microwave irradiation.

Creating an animal fracture model. The entire operation process was performed in operating room aseptic conditions. Intravenous sodium pentobarbital $(30 \mathrm{mg} / \mathrm{kg})$ anesthesia was administered to the rabbits via the ear vein. Following preoperative hair removal, the rabbits were fixed on the experiment table in the dorsal position and the right hind limb skin was sterilized. The right femur was exposed laterally via a longitudinal skin incision $(3-4 \mathrm{~cm})$, with care taken to minimize disruption of the periosteum. Under vertical loading in the middle of the femur, a transverse osteotomy with a $3.0-\mathrm{mm}$ gap was created and stabilized with an internal fixation system (DePuy Synthes Biomaterials, West Chester, PA, USA), which consisted of a titanium alloy plate $(4.58 \pm 0.24 \times 0.41 \pm 0.08 \mathrm{~cm})$ with seven holes and screws. After washing the incision with pure iodine liquid, the wound was closed in layers in the usual manner and covered with sterile dry gauze. Rabbits were transferred to a warm recovery room and monitored until awakening from anesthesia. No wound complications or mortalities occurred within 3 days postoperatively, during which time rabbits received daily intramuscular injections of penicillin (800,000 units per rabbit per day).

Microwave diathermy. Rabbits in group B began receiving $25 \mathrm{~W}$ microwave treatment on postoperative day 4 . Those rabbits were fixed with a specialized fixture to prevent movement during the course of therapy. Prior to treatment, a wattmeter (Enraf Nonius B.V., Rotterdam, The Netherlands) was utilized to adjust the actual output power of the microwave to meet the experimental requirements, and a shelter was used to minimize radiation exposure to the tissues close to the irradiation target. The microwave diathermy system had two main components: A 2450-MHz microwave generator (PM-800; ITO Physiotherapy and Rehabilitation Co., Ltd., Tokyo, Japan) and a non-contact applicator (RM-170A; ITO Physiotherapy and Rehabilitation Co., Ltd.). Microwave treatment was perpendicularly applied $10 \mathrm{~cm}$ away from the right upper thigh for 15 days for $10 \mathrm{~min}$ per day. The same treatment regimen was provided to group $\mathrm{C}$ with a microwave power of 50 W. Group A did not receive any treatment. Microwave treatments were administered at the same time each day to eliminate factors that may influence the interference.

Sampling. After 15 days of treatment, rabbits were humanely euthanized by lethal injection of sodium pentobarbital under strictly sterile conditions in the operating room. Hind limbs were soaked with $75 \%$ ethanol disinfectant for $5 \mathrm{~min}$ and the skin of the hind limb was opened with sharp scissors to expose the quadriceps femoris muscle adjacent to the fracture. By holding the muscle through its tendons, the muscles were excised and trimmed of fat and connective tissue carefully to avoid damaging the myofibers. Each individual muscle sample was divided into two immediately: One was used for electron microscope observation, and the other was used for cell culture. Fig. 1 illustrates the whole protocol in a simplified sequence flow diagram.

Transmission electron microscopy (TEM) examinations of muscle tissue. The muscle tissue was first fixed with $2.5 \%$ glutaraldehyde in phosphate buffer ( $\mathrm{pH} 7.0$ ) overnight at $4^{\circ} \mathrm{C}$, postfixed with $1 \% \mathrm{OsO}_{4}$ in phosphate buffer $(\mathrm{pH} 7.0)$ for $1 \mathrm{~h}$ at $4^{\circ} \mathrm{C}$ and dehydrated in a graded series of ethanol $(30,50,70,80$, 90,95 and $100 \%$ ) for $\sim 15$ min at each step. Following infiltration with a mixture of acetone and resin, specimens were placed in 


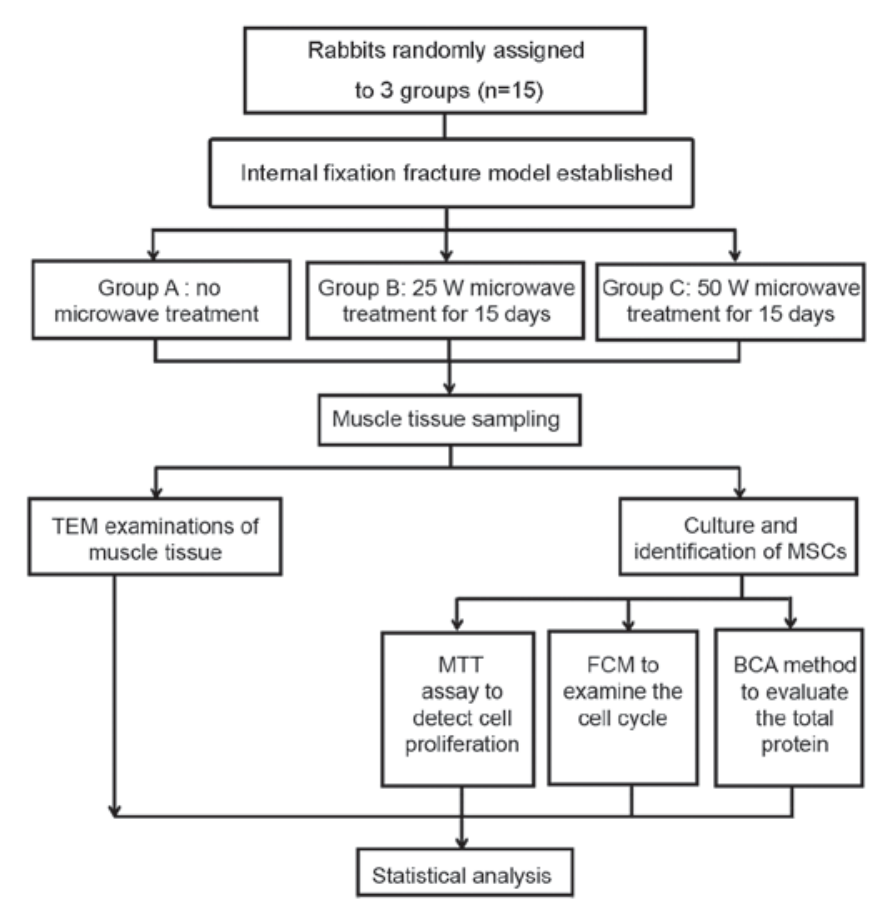

Figure 1. Flow diagram of experimental protocol. TEM, transmission electron microscopy; MSCs, muscle satellite cells; FCM, flow cytometry.

capsules containing embedding medium (epoxy resin; Beijing Solarbio Science \& Technology Co., Ltd., Beijing, China) and heated at $70^{\circ} \mathrm{C}$ overnight. The ultrathin sections (90 nm thick) were stained using uranyl acetate and alkaline lead citrate at room temperature for $15 \mathrm{~min}$ and observed with an electron microscope (EM400T; Phillips Healthcare, Amsterdam, The Netherlands).

Isolation, purification and culture of MSCs. MSCs were obtained from the rabbits using the tissue explant method (29). Briefly, a $2 \mathrm{~cm}^{3}$ skeletal muscle biopsy was harvested from the quadriceps femoris muscle as described above in sampling. The isolated muscle biopsy was cut with ophthalmic scissors in dishes and minced into smaller cubes approximately $1 \mathrm{~mm}^{3}$ along the length of the fibers. The minced muscles were rinsed well with phosphate-buffered saline (PBS), and the tissues that floated on the surface of the liquid were removed. The minced muscles were placed evenly in an empty culture flask with ophthalmic forceps and left for $30 \mathrm{~min}$ to help the adherence of the explants. A growth medium (Dulbecco's modified Eagle's medium supplemented with $10 \%$ fetal bovine serum and $100 \mathrm{U} / \mathrm{ml}$ penicillin-streptomycin; Gibco; Thermo Fisher Scientific, Inc., Waltham, MA, USA) was added to the flask, then cultured in a standard cell incubator at $37^{\circ} \mathrm{C}$ for 9 days. After using a modified differential adhesion method to remove fibroblasts, the purified MSCs were transferred to three fresh poly-L-lysine-coated flasks and cultured for 7 days at $37^{\circ} \mathrm{C}$, in an atmosphere containing $5 \% \mathrm{CO}_{2}$ in a standard cell incubator. The medium was changed every other day. The cells were removed from the culture flask, dissociated with trypsin (Beijing Solarbio Science \& Technology Co., Ltd.) until small holes formed in the opaque monolayer. Cells were subsequently diluted, plated in three fresh flasks and subcultured when the culture reached $\sim 80 \%$ confluence. The morphology and growth features of the cells were observed daily using an inverted microscope.

Immunocytochemical identification of satellite cells. Fourth generation cells were chosen as testing cells and were digested with trypsin, seeded at a density of $1 \times 10^{5}$ cells/well in 6-well plates precoated with poly-L-lysine, and subsequently cultured with the growth medium. When cell confluence reached $80 \%$, they were used for immunocytochemistry. Briefly, the culture medium was discarded and cells were fixed with prewarmed $4 \%$ paraformaldehyde for $10 \mathrm{~min}$ at room temperature. Cells were extensively washed in PBS three times for $5 \mathrm{~min}$, blocked with $3 \% \mathrm{H}_{2} \mathrm{O}_{2}$ diluted with distilled water for $10 \mathrm{~min}$ at room temperature in the dark to deactivate the endogenous peroxidase, and further blocked with 5\% goat serum (Sigma-Aldrich; Merck KGaA, Darmstadt, Germany) for $30 \mathrm{~min}$ at room temperature. Cells were subsequently incubated overnight at $4^{\circ} \mathrm{C}$ in primary antibody solution $(1: 100$; mouse monoclonal anti- $\alpha$-sarcomeric actin; BM0001; Boster Biological Technology, Pleasanton, CA, USA), and PBS displaced the primary antibody as negative criteria. Cells were washed three times in PBS to remove any unbound antibody, and stained with a Streptavidin Biotin-peroxidase kit (Boster Biological Technology) for $30 \mathrm{~min}$ at room temperature followed by diaminobenzidine staining using a Histostain-Plus kit (Beijing Solarbio Science \& Technology Co., Ltd.) for $15 \mathrm{~min}$ at room temperature.

MTT assay. Following trypsinization, cells in the logarithmic growth phase formed a single cell suspension, and the cell concentration was adjusted to $5 \times 10^{4}$ cells $/ \mathrm{ml}$. Cells were seeded into 96-well culture plates (100 $\mu \mathrm{l} /$ well) with six replicates used for each group. To avoid the edge effect, the peripheral wells were filled with sterile PBS. Culture medium without cells was used as the blank control group and cultured for 24,48 and $72 \mathrm{~h}$, respectively, at $37^{\circ} \mathrm{C}$. A total of $100 \mu \mathrm{l}$ MTT solution ( $1 \mathrm{mg} / \mathrm{ml}$; Sigma-Aldrich; Merck KGaA) was added to each well, followed by incubation for $4 \mathrm{~h}$ at $37^{\circ} \mathrm{C}$. After centrifugation for $10 \mathrm{~min}$ at $100 \mathrm{x} \mathrm{g}$, the supernatant was discarded and $150 \mu \mathrm{l}$ dimethyl sulfoxide (Sigma-Aldrich; Merck KGaA) was added into each well to fully dissolve the formazan precipitates with gentle agitation for $10 \mathrm{~min}$ at room temperature. The optical density of each well was measured at a wavelength of $570 \mathrm{~nm}$ using a microplate reader (Multiskan FC; Thermo Fisher Scientific, Inc.). The background absorbance of the blank group was subtracted, the value was pooled and averaged, and the cell growth curve was plotted.

Cell cycle analysis by flow cytometry. Logarithmic growth phase cells were incubated in 6 -well plates $(2 \mathrm{ml} /$ well $)$ at a density of $1 \times 10^{5}$ cells $/ \mathrm{ml}$ overnight $\left(>16 \mathrm{~h}\right.$ ) at $37^{\circ} \mathrm{C}$, harvested by $0.2 \%$ trypsinization, washed with cold PBS twice and subsequently fixed in ice-cold $70 \%$ ethanol for $2 \mathrm{~h}$ at $4^{\circ} \mathrm{C}$. The fixed cells were washed with PBS and incubated with $10 \mu 1$ RNase A $(20 \mu \mathrm{g} / \mathrm{ml}$; Sigma-Aldrich; Merck KGaA) in $500 \mu \mathrm{l} \mathrm{PBS}$ at $37^{\circ} \mathrm{C}$ for $30 \mathrm{~min}$ in the dark. The cellular DNA was stained with $500 \mu \mathrm{l}$ of propidium iodide (Beijing Solarbio Science \& Technology Co., Ltd.) solution (50 $\mu \mathrm{g} / \mathrm{ml}$ in PBS) in the dark for $30 \mathrm{~min}$ at room temperature. The DNA content of the stained cells was determined using a FACSCalibur flow cytometer 
(BD Biosciences, San Jose, CA, USA), and the distribution of each phase was immediately analyzed using ModFit LT for Windows 4.1 analysis software (Verity Software House, Inc., Topsham, ME, USA). A total of 10,000 events were observed per sample.

Bicinchoninic acid (BCA) protein assay. The total protein content $(\mathrm{mg} / \mathrm{ml})$ was measured according to the method previously described by Huang et al (30), with slight modifications. Briefly, the medium was discarded and cells were washed with PBS three times. Cells were lysed by adding $0.5 \mathrm{ml} 0.1 \%$ sodium dodecyl sulfate per well for $30 \mathrm{~min}$ at $100^{\circ} \mathrm{C}$, and were subsequently transferred into 96-well plates. A total of $200 \mu \mathrm{l}$ of the BCA Protein Assay Reagent (Boster Biological Technology) was added followed by oscillation for $10 \mathrm{~min}$. Finally, the optical density value was measured at a 562-nm wavelength using a microplate reader and a standard curve was plotted with bovine serum albumin (Gibco; Thermo Fisher Scientific, Inc.) as a standard.

Statistical analysis. Results were presented as the mean \pm standard deviation. All data were processed by SAS 9.1 for Windows (SAS Institute, Inc., Cary, NC, USA). Following the normality test and homogeneity test of variances, one-way analysis of variance was performed to analyze any statistically significant differences among the groups. Pairwise comparisons among the groups were made using the least significant difference and Student-Newman-Keuls methods. $\mathrm{P}<0.05$ was considered to indicate a statistically significant difference.

\section{Results}

General condition of experimental animals. All rabbits survived to the end of the experiment. The wounds were free from bleeding, suppuration and necrosis throughout the postoperative period.

TEM examinations of muscle tissue. The morphology and histology of muscle tissues in the three groups were observed by TEM. In group A, myocytes and myomere structures were integral, myofilaments were well organized, mitochondria appeared normal, and the $\mathrm{Z}$ line, $\mathrm{M}$ line and $\mathrm{H}$ band remained clear (Fig. 2A). Following a 15-day microwave treatment, the majority of muscle cells in group B appeared to have a normal structure, although myofilaments were slightly disarrayed and occasional swelling of myocytes was observed in the treatment field (Fig. 2B). Cells in group C exhibited an unusual morphology; the muscular fibers were twisted and ruptured, the $\mathrm{Z}$ line was vague, local myocytes were partially dissolved and the mitochondria were swollen (Fig. 2C). Submicroscopic morphological findings revealed that no marked abnormal morphological changes occurred in groups $\mathrm{A}$ and $\mathrm{B}$; however, the muscle damage in group $\mathrm{C}$ was severe.

Morphological characteristics of MSCs. A few cells grew from explanted tissue on the second day of culture in groups A and B. On day 3, the outgrowth of cells also occurred in group C. The cells were round or spherical, sparsely distributed in the flask and had a small cell body. Although the cell morphologies of the three groups were the same, a greater number of outgrown cells were observed in group B compared with group $\mathrm{A}$, and the fewest cells were observed in group C (Fig. 3A-C). On day 7, the speed of cell growth increased and the number of cells observed increased markedly. Cells in groups $\mathrm{A}$ and $\mathrm{C}$ had an ellipsoid or short shuttle-like form and were large with high refraction. Cells in group B changed to fusiform and displayed obvious orientation, with parallel longitudinal axes (Fig. 3D-F). The MSCs were passaged when they approached $80 \%$ confluence, $\sim 9$ days later. At that time, the growth rate declined due to contact inhibition and adjacent cells began to fuse and form myotube-shaped cells that decreased gradually in width but increased in length, and exhibited typical spontaneous contraction. After passage, the cells grew even more rapidly, spread more and exhibited a spindle shape. They were flat, elongated and evenly distributed (Fig. 3G-I). Cells grew steadily after eight passages, and the amount and quality of the cells in the fourth to sixth passage met the requirements for the follow-up experiments.

Identification of MSCs. Immunohistochemistry staining results revealed that the cultured cells in all groups had strong positive staining by the mouse monoclonal anti- $\alpha$-sarcomeric actin in the cytoplasm, while the negative control group had no reaction with PBS. The cultured cells expressed $\alpha$-sarcomeric actin, which confirmed the cells were MSCs. Staining also demonstrated that there was a high quantity and purity $(>95 \%)$ of cells (Fig. 4A-D).

MTT assay. MTT assays were performed to examine the effects of 25 and $50 \mathrm{~W}$ microwave irradiation on cell viability in MSCs. The results were plotted as the MTT curve, which demonstrated that cell viability of the three groups was enhanced gradually with time (Fig. 5). At 24 h no statistical differences were observed in cell viability among the three groups; however, at 48 and $72 \mathrm{~h}$, the MSC viability in group $\mathrm{B}$ was significantly greater compared with group A $(\mathrm{P}<0.01)$. Furthermore, a significant decrease in cell viability was observed in group $\mathrm{C}$ at 48 and $72 \mathrm{~h}$ compared with group $\mathrm{A}$ $(\mathrm{P}<0.01)$. These results demonstrated that microwave treatment affects the viability of MSCs in a time- and dose-dependent manner. The results indicated that $25 \mathrm{~W}$ microwave irradiation had a positive effect on cell proliferation, whereas $50 \mathrm{~W}$ microwave irradiation significantly inhibited the proliferation of MSCs.

Cell cycle analysis. To investigate the effects of microwave treatment on the cell cycle of MSCs, the distribution of MSCs in different phases of the cell cycle was assessed using flow cytometry (Fig. 6). The percentage of cells in the G0/G1, G2/M, S-phase, and the proliferation index (PI) were 72.01, $12.14,15.85$ and $27.99 \%$ in group $A, 61.61,14.37,24.02$ and $38.39 \%$ in group B, and $72.76,11.97,15.2$ and $27.24 \%$ in group $\mathrm{C}$, respectively. Treatment with $50 \mathrm{~W}$ microwave (group C) resulted in a significant decrease in the PI and cells in the S-phase compared with group A $(\mathrm{P}<0.05)$, suggesting that the proliferation ability of cells was inhibited. No significant difference was observed in the $\mathrm{G} 2 / \mathrm{M}$ phase cell percentage. Treatment with $25 \mathrm{~W}$ microwave (group B) had the opposite effect to $50 \mathrm{~W}$; the PI and percentage of cells in the G2/M and 
A

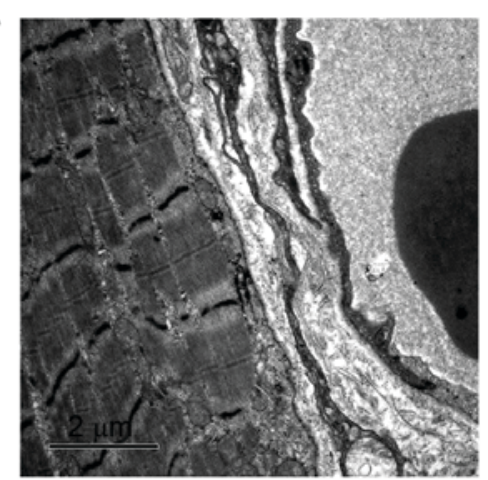

B

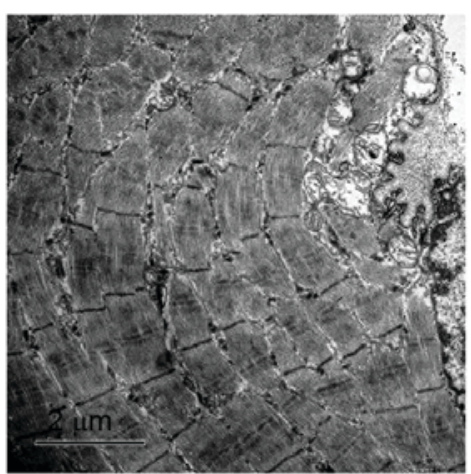

C

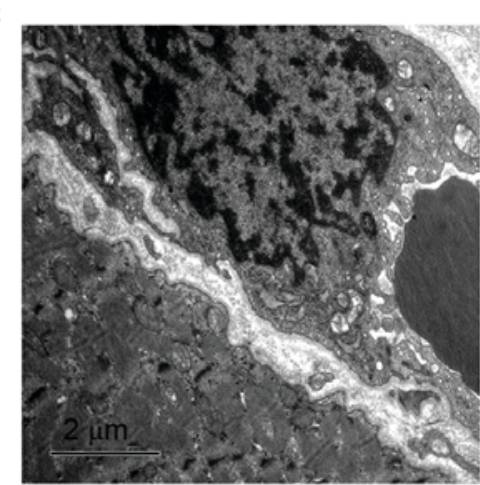

Figure 2. Transmission electron microscopy examination of muscle tissue. (A) No abnormal morphological changes in the group A. (B) Muscle cells in group B possessed a basic structure, and occasionally swelling myocytes (red arrow) were observed. (C) Muscular fibers in group C were ruptured, the Z line was vague (red arrow), local myocytes were partially dissolved and mitochondria were swollen. Scale bar, $2 \mu \mathrm{m}$. Group A, control group; group B, $25 \mathrm{~W}$ microwave treatment; group C, $50 \mathrm{~W}$ microwave treatment.
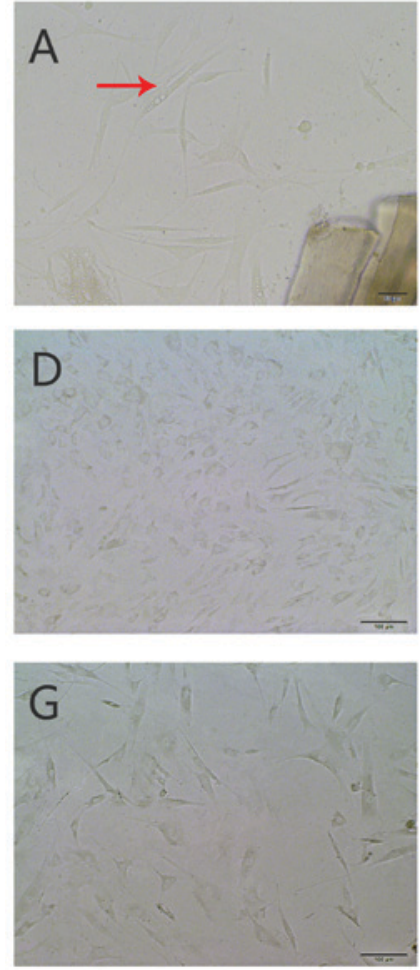
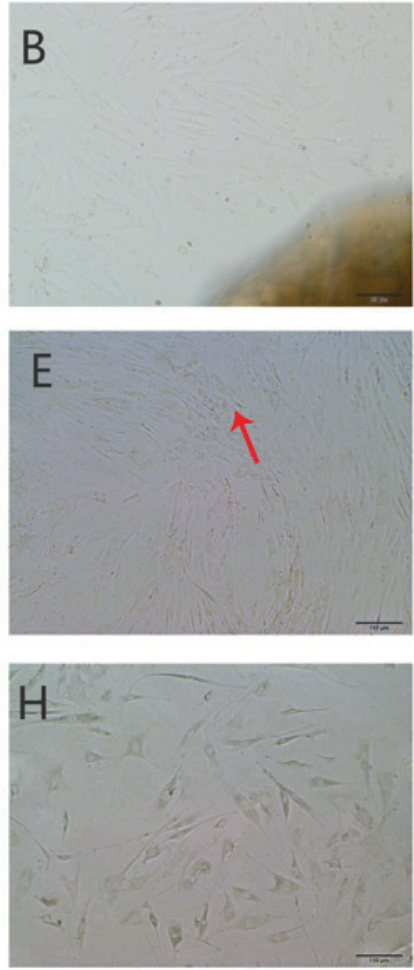
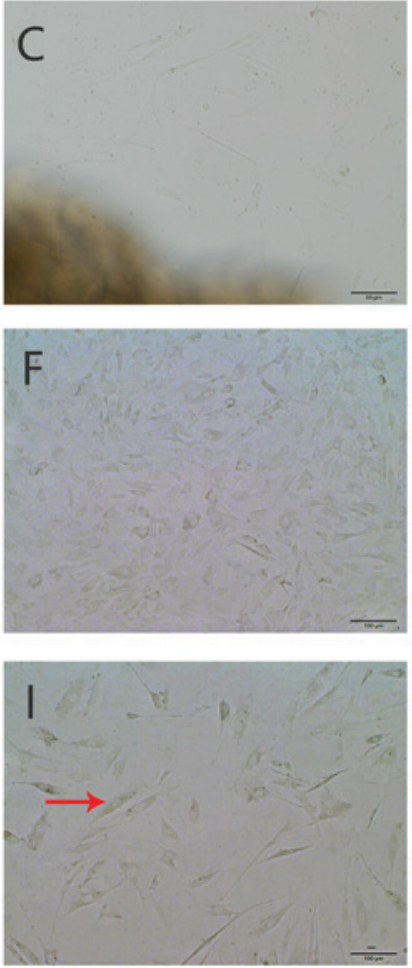

Figure 3. Morphological observations of muscle satellite cells in vitro (magnification, x200). Cell morphology of primary cell culture on day 3 in groups (A) A, (B) B and (C) C. Cells were round or spherical (red arrow), a greater number of outgrown cells were observed in group B compared with group A, and the fewest cells were observed in group C. Primary cell culture on day 7 in groups (D) A, (E) B and (F) C. Cells in groups A and C had an ellipsoid or short shuttle-like form, cells in group B changed to fusiform (red arrow). Cell sub-culture on day 3 in groups $(G) A,(H) B$ and (I) C, cells exhibited a spindle shape. They were flat, elongated and evenly distributed (red arrow). Group A, control group; group B, $25 \mathrm{~W}$ microwave treatment; group C, $50 \mathrm{~W}$ microwave treatment.

S-phase were significantly increased $(\mathrm{P}<0.05)$ compared with group A, indicating that the proliferative capacity was greater, the proliferation cycle was shorter and more cells entered the mitotic phase.

$B C A$ protein assay. The total protein content of MSCs cultured at 24,48 and $72 \mathrm{~h}$ was measured using the BCA protein assay. The results revealed that the total protein content at 24,48 and $72 \mathrm{~h}$ was significantly higher in group B compared with the group A $(\mathrm{P}<0.05$; Fig. 7). At $24 \mathrm{~h}$ there was no statistical difference between groups $\mathrm{A}$ and $\mathrm{C}$, whereas the total protein content in group $\mathrm{C}$ at 48 and $72 \mathrm{~h}$ was significantly lower than in group A $(\mathrm{P}<0.05$; Fig. 7). These findings indicated that $25 \mathrm{~W}$ microwave treatment may induce an increase in total protein, whereas $50 \mathrm{~W}$ microwave treatment reduces it. These results were consistent with the cell proliferation analysis.

\section{Discussion}

A large number of animal experimental and clinical studies have demonstrated that microwaves are able to stimulate the 
A

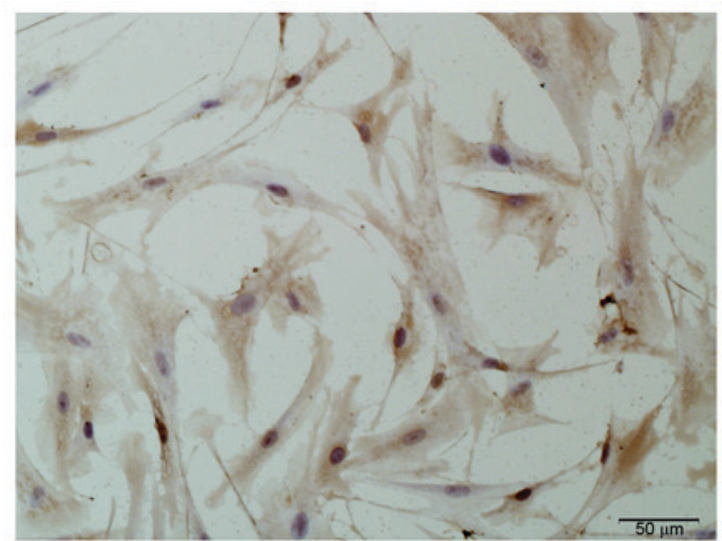

C

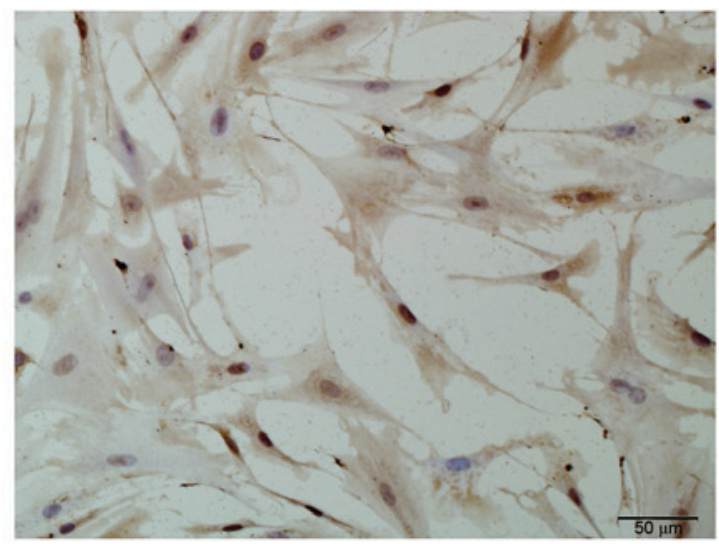

B

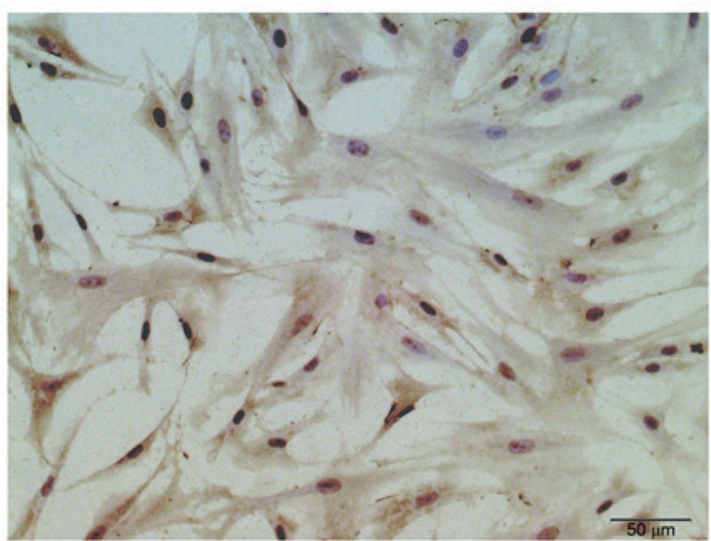

D

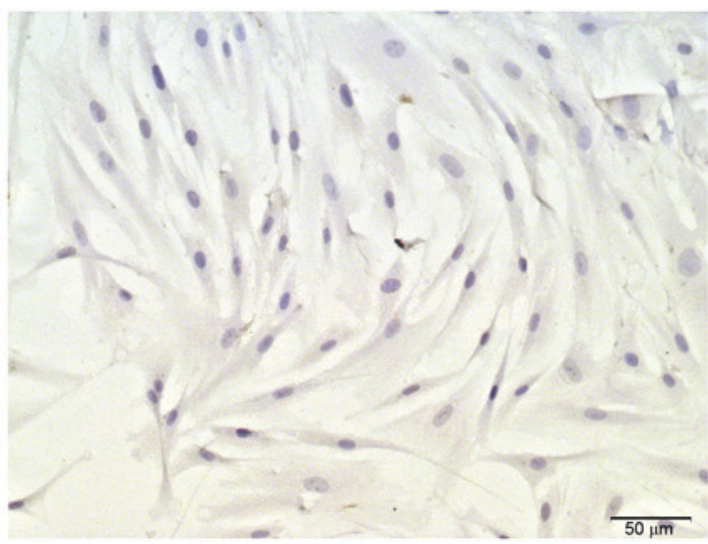

Figure 4. $\alpha$-sarcomeric actin immunocytochemical identification of satellite cells (magnification, x200; scale bar, $50 \mu$ m). Positive brown staining of the cytoplasm was observed in groups (A) A, (B) B and (C) C. (D) Negative reaction staining with phosphate-buffered saline. Group A, control group; group B, $25 \mathrm{~W}$ microwave treatment; group $\mathrm{C}, 50 \mathrm{~W}$ microwave treatment.

proliferation and differentiation of osteoblasts (31-33). As a noninvasive physical factor, microwaves have served an important role in promoting the rehabilitation of fractures with delayed union and nonunion in recent years $(17,18)$. Historically, microwaves have not been used on metallic alloys due to the theory that when metallic alloys are exposed to microwaves, the reflection and eddy current generate too much heat to damage the surrounding tissues, particularly muscle $(20,34,35)$. Skeletal muscle regenerates poorly, and so such damage would cause permanent division and proliferation incapacity and irreversible loss of function. The unique properties of titanium alloy provide an opportunity to investigate the effects of microwaves. Ye et al $(27,28)$ demonstrated that $25 \mathrm{~W}$ microwave $(2,450 \mathrm{MHz})$ promoted fracture rehabilitation in an animal model with a titanium alloy implant with no dramatic increase in heat $\left(<41^{\circ} \mathrm{C}\right)$. To the best of our knowledge, the effect of microwaves on the skeletal muscles adjacent to fracture sites has not yet been investigated, hindering the application of this technique.

MSCs are located between the sarcolemma and basement membrane of muscle fiber cells, are able to proliferate and self-renew, and are regarded as myogenic precursors (36). In normal physiological conditions, MSCs are dormant or quiescent $(37,38)$. They are activated to enter the cell cycle in response to muscle damage and, when they migrate to the damaged areas, they proliferate and differentiate into multinuclear myotubes to help repair and regenerate the injured

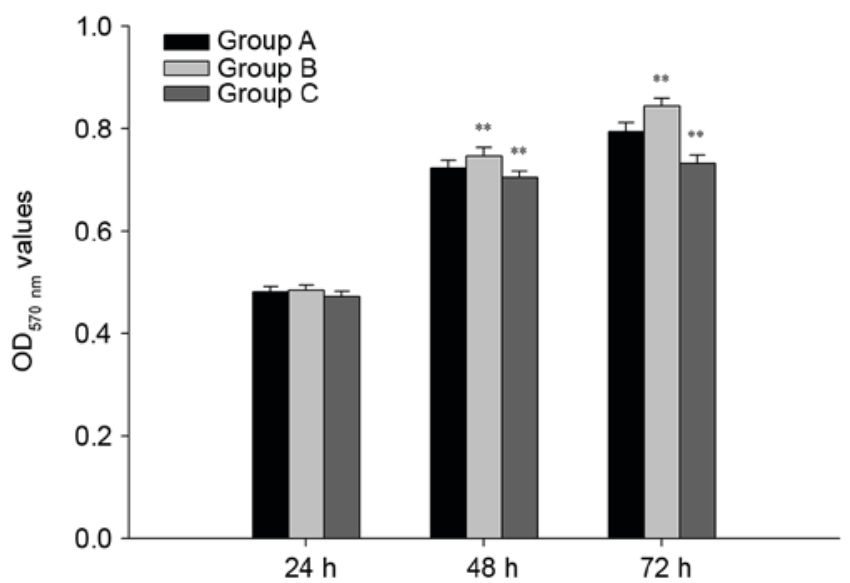

Figure 5. MTT assay of MSCs. (A and B) At 24, 48 and 72 h, an MTT assay was conducted to assess MSC viability. No statistical differences were observed in cell viability at $24 \mathrm{~h}$. At 48 and $72 \mathrm{~h}$, MSC viability was significantly increased in group $\mathrm{B}$ and decreased in group $\mathrm{C}$. ${ }^{* *} \mathrm{P}<0.01$ vs. group $\mathrm{A}$. MSCs, muscle satellite cells; OD, optical density; group A, control group; group B, $25 \mathrm{~W}$ microwave treatment; group C, $50 \mathrm{~W}$ microwave treatment.

muscle tissues $(39,40)$. Therefore, whether the proliferative ability of MSCs is normal has a direct impact on maintaining and repairing the structure and function of damaged skeletal muscle. The present study explored the effect of microwaves on the proliferative ability of MSCs in fractures with titanium 

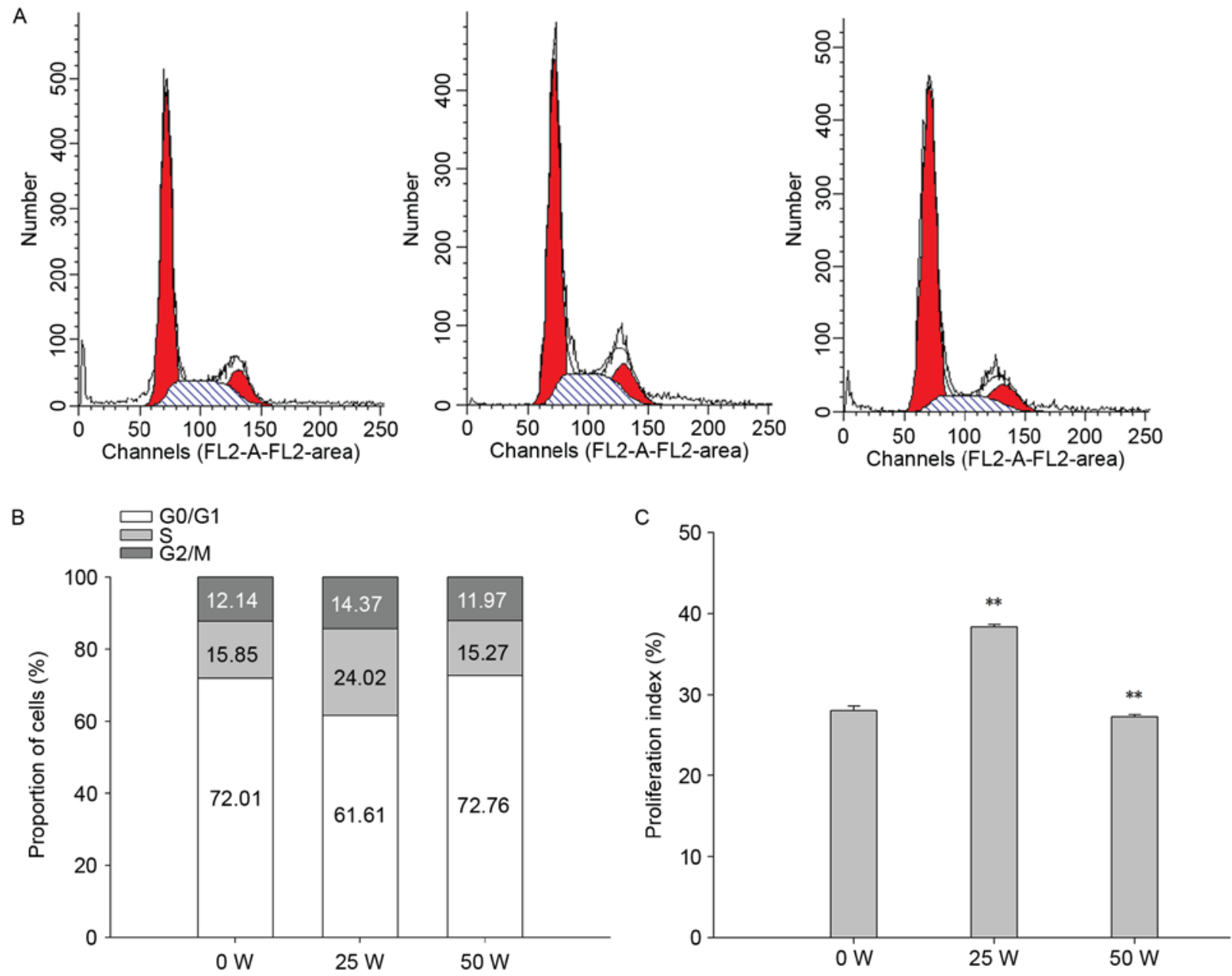

Figure 6. Cell cycle analysis of MSCs. (A) Distribution of MSCs in the three phases of the cell cycle as determined by flow cytometry analysis. (B) The proportion of MSCs in the G0/G1, S and G2/M phases. (C) The proliferation index significantly increased in group B and decreased in group ${ }^{* *} \mathrm{P}<0.01$ vs. group A. MSCs, muscle satellite cells; group A, control group; group B, $25 \mathrm{~W}$ microwave treatment; group C, $50 \mathrm{~W}$ microwave treatment.

alloy implants to verify the efficacy of this therapy and provide a scientific basis for future clinical use.

Although muscle cells may suffer damage or loss, the basement membrane and satellite cells are retained, which provides a structural framework and cell component for muscle regeneration (41). In the present study, TEM images indicated that the skeletal muscles in the experimental groups were both damaged to different degrees following 15 days of treatment. Compared with group A, group B exhibited only minor histopathological changes, whereas cells in group $\mathrm{C}$ were badly damaged. The results demonstrated that the muscle tissue of group B was in a favorable state compared with group C.

In the present study, the tissue explant method was used to cultivate the primary MSCs due to its simple operation and cost-effective use (42). The disadvantage of this approach is that the target cells mix with cell debris and impure cells (43). The modified differential adhesion method is an effective approach for purifying satellite cells (44). Fibroblast-like cells are removed as they are better at adhesion and grow faster than satellite cells. In the present study, exposure to $25 \mathrm{~W}$ microwave treatment resulted in earlier MSC generation compared with the other two groups. The results of the present study demonstrated that cells in group B possessed exuberant proliferation capacity and activity in the early phase of cell

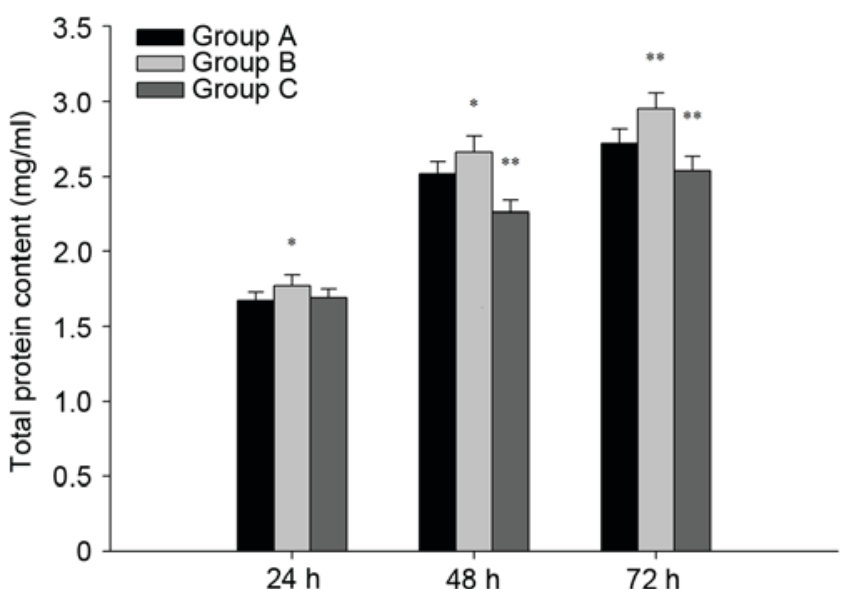

Figure 7. Total protein content of skeletal muscle satellite cells. The total protein content at 24,48 and $72 \mathrm{~h}$ was highest in group B. At $24 \mathrm{~h}$ there was no statistical difference between groups $\mathrm{A}$ and $\mathrm{C}$, and the protein content of group $\mathrm{C}$ was lower at 48 and $72 \mathrm{~h}$ than in group $\mathrm{A} .{ }^{*} \mathrm{P}<0.05$ and ${ }^{* *} \mathrm{P}<0.01$ vs. group A. Group A, control group; group B, $25 \mathrm{~W}$ microwave treatment; group $\mathrm{C}, 50 \mathrm{~W}$ microwave treatment.

culture. The out growing cells in group $\mathrm{C}$ began proliferating after 3 days, comparatively late compared with the other 
groups. The number of cells in group $\mathrm{C}$ was also the lowest. The proliferation and self-renewing abilities of MSCs depend largely on the magnitude of the damage; due to the relatively minor damage, cells in group B were activated to proliferate from early on. Severe damage may disrupt the mechanisms of proliferation and compromise the ability to regulate it (45).

To confirm that cultivated cells were muscle-derived cells, specific markers of skeletal muscle were identified. $\alpha$-sarcomeric actin is one of the acknowledged specific marker proteins, and is a structural and functional protein of skeletal muscle that does not exist in smooth muscle cells $(46,47)$. Using $\alpha$-sarcomeric actin monoclonal antibodies for immunocytochemistry ascertained that the MSCs were skeletal MSCs and also determined that they were 95\% pure. The remaining negative cells were most likely fibroblasts. A study by Motohashi et al (48) previously obtained satellite cells with a purity of $99 \%$ or more by using magnetic activated cell sorting. This approach has a higher purification rate, but requires complicated processes and higher costs. In the present study, 95\% purification fulfilled the experimental requirements; however, in future studies the purification and culture conditions should be further optimized.

Cell viability may be measured either in vivo or in vitro using cell culture techniques, such as MTT assays. Both in vivo and in vitro assays have their own pros and cons. In vitro assays are typically used to examine cell viability at specific time points and are frequently applied in scientific research work due to their simplicity, speed and accuracy (49). In vivo assays, however, are able to identify more integrated and dynamic changes in cell viability (50). In the present study, the MTT assay was used to explore the number of viable MSCs at different microwave powers. Compared with a single time point, plotting a growth curve allows for a more comprehensive understanding of the growth characteristics of MSCs. In general, the proliferation ability increases over time. No statistical differences were observed in proliferation ability at $24 \mathrm{~h}$, but at 48 and $72 \mathrm{~h}$ the MSC proliferation in group B was the strongest and in group $\mathrm{C}$ was the poorest. The results indicated that $25 \mathrm{~W}$ microwave treatment significantly promoted the proliferation of MSCs and that $50 \mathrm{~W}$ microwave treatment had a negative effect on cell proliferation. The effect of thermal damage induced by microwave therapy may be accumulated (51), so the severity of damage is time- and temperature-dependent. It has been reported that absorbing microwaves and alternating magnetic fields generate a thermal effect and may cause tissue heating, which provokes heat stress (HS) (52). Studies have reported that HS is able to protect cells from free radical damage by activating the protein kinase B (Akt)/mechanistic target of rapamycin signaling pathway and inducing superoxide dismutase activity $(53,54)$. Heat shock proteins are produced under heat stress and mediate various cellular processes to provide buffering against the accumulative action and improve thermotolerance (55-57). Many studies have reported that when heat stress increases beyond the critical point, this protective mechanism fails $(58,59)$. Extended exposure to high temperatures may cause permanent and irreversible damage, which may explain why different microwave powers had different effects on proliferation.

The effects of different microwave powers on the cell cycle were investigated using flow cytometry. In the S phase (DNA synthesis), a higher percentage indicates a greater proliferating potential. The percentage of $\mathrm{S}+\mathrm{G} 2 / \mathrm{M}$ is $\mathrm{PI}$, which represents the proportion of cells in the proliferating stage and reflects the cell proliferation state. PI and S-phase fractions were highest in group B and were lowest in group A. The results demonstrated that $25 \mathrm{~W}$ microwave treatment enhanced proliferation and $50 \mathrm{~W}$ microwave treatment inhibited it. Microwaves may accelerate DNA synthesis and promote entrance to the cell cycle by initiating extracellular signal-regulated protein kinase and phosphoinositide 3-kinase/Akt signal transduction pathways $(60,61)$. Studies have also reported that exposure to hyperthermia may arrest cell division, which is achieved via influencing the expression of cell cycle regulatory proteins $(62,63)$. The underlying mechanism responsible for this remains unclear.

Cell protein content is typically used to estimate the amount of a substance in cells, but may also be used in growth experiments (64). Compared with group A, the protein content in group B was increased and was decreased in group $\mathrm{C}$, which was consistent with other experimental results.

In conclusion, the results of the present study indicated that microwave therapy influences MSC proliferation in fractures with titanium alloy internal fixation. Treatment with $25 \mathrm{~W}$ microwaves promotes MSC proliferation, whereas $50 \mathrm{~W}$ inhibits it. These results indicate that it is safe to use $25 \mathrm{~W}$ microwave therapy on fractures with titanium alloy fixation and provides a scientific basis for future clinical use. In future studies, the effect of $25 \mathrm{~W}$ microwave therapy on the proliferation of nerves adjacent to titanium alloy implants should be investigated to provide more evidence for the therapy's safe use.

\section{Acknowledgements}

The authors wish to thank Dr Xianxuan Feng for her excellent technical assistance with the transmission electron microscopy examinations.

\section{Funding}

No funding was received.

\section{Availability of data and materials}

The datasets used and/or analyzed during the current study are available from the corresponding author on reasonable request.

\section{Authors' contributions}

YB conceived and designed the experiments. YZ, GW and YX performed the experiments. $\mathrm{YZ}$ analyzed the data. $\mathrm{YB}$ and $\mathrm{YZ}$ contributed reagents/materials/analysis tools. $\mathrm{YZ}$ wrote the paper.

\section{Ethics approval and consent to participate}

All animal welfare and experimental procedures involving animals were conducted in strict conformity with the recommendations in the Guide for the Care and Use of Laboratory Animals of National Laboratory Animals and protocols were 
specifically approved by the Animal Welfare and Ethics Committee of Shanghai Sixth People's Hospital [Permit no. SYXK (HU) 2011.0128; Shanghai, China].

\section{Patient consent for publication}

Not applicable.

\section{Competing interests}

All authors declare that they have no competing interests.

\section{References}

1. Liang CZ, Ma F, Wu YP and Li Y: Survey on the basic situation of the bone fractue in rural population of China. Yi Xue Yan Jiu Za Zhi 31: 10-12, 2002 (In Chinese).

2. Perren SM: Fracture healing. The evolution of our understanding. Acta Chir Orthop Traumatol Cech 75: 241-246, 2008.

3. Adam P: Treatment of recent trochanteric fracture in adults. Orthop Traumatol Surg Res 100 (Suppl 1): S75-S83, 2014.

4. Yu X, Pang QJ, Chen L, Yang CC and Chen XJ: Postoperative complications after closed calcaneus fracture treated by open reduction and internal fixation: A review. J Int Med Res 42: 17-25, 2014.

5. Lynch NM and Linscheid RL: Corrective osteotomy for scaphoid malunion: Technique and long-term follow-up evaluation. J Hand Surg 22: 35-43, 1997,

6. Young MJ and Barrack RL: Complication of internal fixation of plateau fractures. J Orthop Rev 23: 149-153, 1994.

7. Moore TM, Patzakis MJ and Harvey JP: Tibial plateau fractures: Definition, demographics, treatment rationale, and long-term results of closed traction management or operative reduction. J Orthop Trauma 1: 97-119, 1987.

8. Einhorn TA: Enhancement of fracture-healing. J Bone Joint Surg 77: 940-956, 1995

9. Kim SH, Szabo RM and Marder RA: Epidemiology of humerus fractures in the United States: Nationwide emergency department sample, 2008. Arthritis Care Res (Hoboken) 64: 407-414, 2012.

10. World Health Organization (WHO): The Global Burden of Disease: 2004 update. WHO, Geneva, 2008.

11. Ji Z, Ma Y, Li W, Li X, Zhao G, Yun Z, Qian J and Fan Q: The healing process of intracorporeally and in situ devitalized distal femur by microwave in a dog model and its mechanical properties in vitro. PLoS One 7: e30505, 2012.

12. Cavaliere R, Ciocatto EC, Giovanella BC, Heidelberger C, Johnson RO, Margottini M, Mondovi B, Moricca G and Rossi-Fanelli A: Selective heat sensitivity of cancer cells. Biochemical and clinical studies. Cancer 20: 1351-1381, 1967.

13. Liebergall M, Abu-Sneineh CH, Eylon S, Mendelson S, Segal D and Simkin A: Effect of microwave oven induced mild hyperthermia on bone viability and strength. Clin Orthop Relat Res 372: 272-279, 2000.

14. Song CW: Effect of local hyperthermia on blood flow and microenvironment: A review. Cancer Res 44 (Suppl 10): S4721-S4730, 1984.

15. Wyper DJ and McNiven DR: The effect of microwave therapy upon muscle blood flow in man. Br J Sports Med 10: 19-21, 1976

16. Sekins KM, Lehmann JF, Esselman P, Dundore D, Emery AF, deLateur BJ and Nelp WB: Local muscle blood flow and temperature responses to $915 \mathrm{MHz}$ diathermy as simultaneously measured and numerically predicted. Arch Phys Med Rehabil 65: $1-7,1984$

17. Leon SA, Asbell SO, Edelstein G, Arastu HH, Daskal I, Sheehan S, Plunkett DM, Guttmann GG, Packel AJ and Leon O: Effects of hyperthermia on bone. I. Heating rate patterns induced by microwave irradiation in bone and muscle phantoms. Int J Hyperthermia 9: 69-75, 1993.

18. Leon SA, Asbell SO, Arastu HH, Edelstein G, Packel AJ, Sheehan S, Daskal I, Guttmann GG and Santos I: Effects of hyperthermia on bone. II. Heating of bone in vivo and stimulation of bone growth. Int J Hyperthermia 9: 77-87, 1993.

19. Chang WH, Sun JS, Chang SP and Lin JC: Study of thermal effects of ultrasound stimulation on fracture healing. Bioelectromagnetics 23: 256-263, 2002.
20. McIntosh RL, Anderson V and McKenzie RJ: A numerical evaluation of SAR distribution and temperature changes around a metallic plate in the head of a RF exposed worker. Bioelectromagnetics 26: 377-388, 2005.

21. Ruggera PS, Witters DM, von Maltzahn G and Bassen HI: In vitro assessment of tissue heating near metallic medical implants by exposure to pulsed radio frequency diathermy. Phys Med Biol 48: 2919-2928, 2003.

22. Martin CJ, McCallum HM and Heaton B: An evaluation of radiofrequency exposure from therapeutic diathermy equipment in the light of current recommendations. Clin Phys Physiol Meas 11: 53-63, 1990.

23. Kobayashi E, Matsumoto S, Doi H and Hamanaka H: Mechanical properties of the binary titanium-zirconium alloys and their potential for biomedical materials. J Biomed Mater Res 29: 943-950, 1995.

24. Donachie M: Biomedical alloys. Adv Materials Proc 154: 63-65, 1998 .

25. Lee MJ, Kim S, Lee SA, Song HT, Huh YM, Kim DH, Han SH and Suh JS: Overcoming artifacts from metallic orthopedic implants at high-field-strength MR imaging and multi-detector CT. RadioGraphics 27: 791-803, 2007.

26. Virtanen H, Huttunen J, Toropainen A and Lappalainen R: Interaction of mobile phones with superficial passive metallic implants. Phys Med Biol 50: 2689-2700, 2005.

27. Ye D, Xu Y, Fu T, Zhang H, Feng X, Wang G, Jiang L and Bai Y: Low dose of continuous-wave microwave irradiation did not cause temperature increase in muscles tissue adjacent to titanium alloy implants-an animal study. BMC Musculoskelet Disord 14: 364, 2013.

28. Ye D, Xu Y, Zhang H, Fu T, Jiang L and Bai Y: Effects of low-dose microwave on healing of fractures with titanium alloy internal fixation: An experimental study in a rabbit model. PLoS One 8: e75756, 2013.

29. Rando TA and Blau HM: Primary mouse myoblast purification, characterization, and transplantation for cell-mediated gene therapy. J Cell Biol 125: 1276-1287, 1994.

30. Huang T, Long M and Huo B: Competitive binding to cuprous ions of protein and bca in the bicinchoninic acid protein assay. Open Biomed Eng J 4: 271-278, 2010.

31. LI L and Zhang CY: Experimental research and mechanism of electric stimulation osteogenesis. Chin J Orthop 17: 4707-4714, 1990.

32. Jaecques S, Helsen JA, Maertens S and Lammens J: Electric stimulation of osteogenesis by dynamically loaded piezoelectric films: An in vivo exploration in rabbits. Proc 13th Eur Conf Biomaterials, p15, 1997.

33. Haddad JB, Obolensky AG and Shinnick P: The biologic effects and the therapeutic mechanism of action of electric and electromagnetic field stimulation on bone and cartilage: New findings and a review of earlier work. J Altern Complement Med 13: 485-490, 2007.

34. Skonieczki BD, Wells C, Wasser EJ and Dupuy DE: Radiofrequency and microwave tumor ablation in patients with implanted cardiac devices: Is it safe? Eur J Radiol 79: 343-346, 2011.

35. Cooper $\mathbf{J}$ and Hombach V: Increase in specific absorption rate in human heads arising from implantations. Electron Let 32: 2217-2219, 1996.

36. Baroffio A, Bochaton-Piallat ML, Gabbiani G and Bader CR: Heterogenecity in the progeny of single human muscle satellite cells. Differentiation 59: 259-268, 1995.

37. Schultz E and McCormick KM: Skeletal muscle satellite cells. Rev Physiol Biochem Pharmacol 123: 213-257, 1994.

38. Snow MH: A quantitative ultrastructure analysis of satellite cells in denervated fast and slow muscles of the mouse. Anat Rec 207: 593-604, 1983.

39. Parker M, Seale P and Rudnicki MA: Looking back to the embryo: Defining transcriptional network in adult myogenesis. Nat Rev Genet 4: 497-507, 2003.

40. Mckinnell IW, Ishibashi J, Le Grand F, Punch VG, Addicks GC, Greenblatt JF, Dilworth FJ and Rudnicki MA: Pax7 activates myogenic genes by recruitment of a histone methyltransferase complex. Nat Cell Biol 10: 77-84, 2008.

41. Christov C, Chrétien F, Abou-Khalil R, Bassez G, Vallet G, Authier FJ, Bassaglia Y, Shinin V, Tajbakhsh S, Chazaud B and Gherardi RK: Muscle satellite cells and endothelial cells: Close neighbors and privileged partners. Mol Biol Cell 18: 1397-1409, 2007.

42. Fu P: Study on culture method of pleural mesothelial cells of rats. J Shanxi College of Trad Chin Med 4, 2009. 
43. Jiang Z, Jiang YQ, Li XG, Li B and Zhou W: Construction of the model of primary cultured human glioma cells. Zhonghua Zhong Liu Fang Zhi Za Zhi 13: 744-747, 2006 (In Chinese).

44. Ding WJ, Tang Y, Song YL, Su ZD, Li C, Liu AT, Hu X and Jiang H: Isolation of murine muscle-derived stem cells with preplate technique combined with limited dilution technique. Zhongguo Zu Zhi Gong Cheng Yan Jiu Yu Lin Chuang Kang Fu 15: 6797-6801, 2011 (In Chinese).

45. Yablonka-Reuveni $\mathrm{Z}$ and Anderson JE: Satellite cells from dystrophic (mdx) mice display accelerated differentiation in primary cultures and isolated myofibers. Dev. Dyn 235: 203-212, 2006.

46. Sejersen $\mathrm{T}$ and Lendahl U: Transient expression of the intermediate filament nestin during skeletal muscle development. J Cell Sci 106: 1291-1300, 1993

47. Yablonka-Reuveni Z, Quznn L and Nameroff M: Isolation and clonal analysis of satellite cells from chicken pectoralis musele. Dev Biol 119: 252-259, 1987.

48. Motohashi N, Asakura Y and Asakura A: Isolation, culture, and transplantation of muscle satellite cells. J Vis Exp 8: e50846, 2014

49. Castro-Concha LA, Escobedo RM and Miranda-Ham ML: Measurement of cell viability in in vitro cultures. Methods Mol Biol 318: 71-76, 2006.

50. Yang PC: Is reliable in vivo detection of stem cell viability possible in a large animal model of myocardial injury? Circulation 126: 388-390, 2012.

51. Shields N, Gormley J and O'Hare N: Short-wave diathermy: Current clinical and safety practices. Physiother Res Int 7: 191-202, 2002

52. Velichko AK, Markova EN, Petrova NV, Razin SV and Kantidze OL: Mechanisms of heat shock response in mammals. Cell Mol Life Sci 70: 4229-4241, 2013.

53. Gao CQ, Zhao YL, Li HC, Sui WG, Yan HC and Wang XQ: Heat stress inhibits proliferation, promotes growth, and induces apoptosis in cultured Lantang swine skeletal muscle satellite cells. J Zhejiang Univ Sci B 16: 549-559, 2015.

54. Lille S, Su CY, Schoeller T, Suchy H, Lyons S, Russell RC, Neumeister M and Lai CC: Induction of heat shock protein 72 in rat skeletal muscle does not increase tolerance to ischemia-reperfusion injury. Muscle Nerve 22: 390-393, 1999.
55. Lindquist S: The heat-shock response. Annu Rev Biochem 55: 1151-1191, 1986.

56. Pelham HRB: Functions of the HSP70 protein family: An overview. CPHI Press, Cold Spring Harbor, NY, pp287-299, 1990.

57. Marber MS: Ischemic preconditioning in isolated cells. Circ Res 86: 926-931, 2000.

58. Li SQ, Li RF, Xi SM, Hu S, Jia ZQ, Li SP, Wen XL, Song YK, Li S, Li SP, et al: Systematical analysis of impacts of heat stress on the proliferation, apoptosis and metabolism of mouse hepatocyte. J Physiol Sci 62: 29-43, 2012.

59. Rezai Rad M, Wise GE, Brooks H, Flanagan MB and Yao S: Activation of proliferation and differentiation of dental follicle stem cells (DFSCs) by heat stress. Cell Prolif 46: 58-66, 2013.

60. Yang SY, Hoy M, Fuller B Sales KM, Seifalian AM and Winslet MC: Pretreatment with insulin-like growth factor 1 protects skeletal muscle cells against oxidative damage via PI3K/Akt an ERK1/2 MAPK pathways. Lab Invest 90: 391-401, 2010.

61. Li Y, Zhang P, Qiu F, Chen L, Miao C, Li J, Xiao W and Ma E: Inactivation of PI3K/Akt signaling mediates proliferation inhibition and $\mathrm{G} 2 / \mathrm{M}$ phase arrest induced by andrographolide in human glioblastoma cells. Life Sci 90: 962-967, 2012.

62. Kühl NM and Rensing L: Heat shock effects on cell cycle progression. Cell Mol. Life Sci 57: 450-463, 2000.

63. Zhang M, Jiang M, Bi Y, Zhu H, Zhou Z and Sha J: Autophagy and apoptosis act as partners to induce germ cell death after heat stress in mice. PLoS One 7: e41412, 2012.

64. Xu L, Huang J and Xiang XR: Effects of osteoblastic growth peptide on the proliferation and total protein content in cultured human periodontal ligament cells. Chongqing Yi Ke Da Xue Xue Bao 34: 420-423, 2009 (In Chinese).

(i) $(\Theta \Theta$ This work is licensed under a Creative Commons (c) $\mathrm{EY}$ No No Attribution-NonCommercial-NoDerivatives 4.0 International (CC BY-NC-ND 4.0) License. 